\title{
Genetic Variation in the Asian Shore Crab Hemigrapsus sanguineus in Korean Coastal Waters as Inferred from Mitochondrial DNA Sequences
}

\author{
Sung-Eic Hong ${ }^{1}$, Jin-Koo Kim ${ }^{2}$, Jeong-Nam Yu ${ }^{3}$, Keun-Yong Kim ${ }^{4}$, Chung Il Lee ${ }^{1}$, Kwan Eui Hong, \\ Kie Young Park ${ }^{1}$ and Moongeun Yoon ${ }^{5 *}$ \\ ${ }^{1}$ Department of Marine Bioscience, Gangneung-Wonju National University, Gangneung 210-702, Korea \\ ${ }^{2}$ Department of Marine Biology, Pukyong National University, Busan 608-737, Korea \\ ${ }^{3}$ Environmental Research Complex, Incheon 404-708, Korea \\ ${ }^{4}$ Department of Marine Biotechnology, Soonchunhyang University, Asan 336-745, Korea \\ ${ }^{5}$ Yangyang Salmon Station, Korea Fisheries Resources Agency, Yangyang 215-851, Korea
}

\begin{abstract}
Genetic variation in the Asian shore crab Hemigrapsus sanguineus was determined from partial mitochondrial DNA (mtDNA) sequences of the cytochrome $b(C y t b)$ gene. Samples included 143 crabs from six localities along three coastlines in South Korea. A nucleotide sequence analysis revealed 38 variable sites in a 470-bp sequence, which defined 37 haplotypes. The haplotypes were not associated geographically and had a shallow genealogy. Pairwise $F_{\mathrm{ST}}$ tests and a two-dimensional scaling analysis revealed no significant genetic differentiation among most of the populations. The low pairwise comparison values, but significant genetic differentiation of a northeastern population from all other populations, might have been influenced by a restriction in gene flow caused by hydrographic conditions such as ocean boundaries. The high haplotype diversity, low nucleotide diversity, and time since $H$. sanguineus expansion in Korean coastal waters indicate rapid population growth and a recent, sudden expansion in the Late Pleistocene.
\end{abstract}

Key words: Cytochrome $b$, Genetic differentiation, Genetic variation, Hemigrapsus sanguineus

\section{Introduction}

The Asian shore crab Hemigrapsus sanguineus is distributed widely in the western Pacific, including Hong Kong, Taiwan, Korean, Chinese, and Japanese coastal waters, and as far north as Sakhalin Island, Russia (Sakai, 1976; Fukui, 1988; Dai and Yang, 1991; Hwang et al., 1993). It is abundant in rocky intertidal habitats and is an ecologically important predator in coastal ecosystems, as are other shore crab species (Kikuchi et al., 1981; Takada and Kikuchi, 1991; McDermott, 1998a, 1998b; Lohrer et al., 2000). In Japan, the breeding season of $H$. sanguineus is March-October, with a main peak
May-June (Fukui, 1988). It has a planktonic larval stage of more than 1 month before developing into the juvenile crab (Fukui, 1988). The larval dispersal pattern and preferred habitat might have caused geographically distinct regional populations to become homogeneous.

Estimating genetic structure among populations using molecular markers has become a common approach to determining sustainable yields and genetic diversity (Dunham, 2004). The population genetic structures of some marine species are influenced by their larval dispersal pattern and behavior after
Open Access http://dx.doi.org/10.5657/FAS.2012.0049

This is an Open Access article distributed under the terms of the Creative Commons Attribution Non-Commercial License (http://creativecommons, org/licenses/by-nc/3.0/) which permits unrestricted non-commercial use, distribution, and reproduction in any medium, provided the original work is properly cited. pISSN: 2234-1749 eISSN: 2234-1757
Received 4 October 2011; $\quad$ Revised 28 November 2011; Accepted 8 February 2012

*Corresponding Author

E-mail: mgyoon5@fira.or.kr 
spawning, which are determined by oceanographic features including sea currents, hydrological conditions, and physical barriers (Doyle et al., 1993; Hsieh et al., 2010). In general, most marine species have limited population substructures and high levels of gene flow because of the effect of sea currents. Ocean structure and dynamics, including current boundaries and hydrographic conditions, have caused reproductive and partial genetic isolation in geographically distinct regional populations (Wares et al., 2001; Bilton et al., 2002).

Although DNA markers are expected to overcome deficiencies in allozyme analysis by increasing the accuracy and resolution of population-structure assessments in crab species (McMillen-Jackson et al., 1994; Creasey et al., 1997), there are few reports on the use of mitochondrial DNA (mtDNA) to measure genetic variation in shore crabs (Cassone and Boulding, 2006). Maternally inherited mtDNA has greater sequence variability than do most nuclear genes (Brown et al., 1979). Moreover, it has a compact genome size in both conserved and variable regions and a conserved gene content and arrangement (Anderson et al., 1981). Therefore, mtDNA analysis has become a key method in evolutionary and ecological studies of crabs (Pfeiler et al., 2005; Cassone and Boulding, 2006; Azuma et al., 2008; Wang et al., 2008).

This study investigated the genetic variation and population structure of $H$. sanguineus in Korean coastal waters using mtDNA cytochrome $b(C y t b)$ sequences to assess phylogeographic and demographic patterns.

\section{Materials and Methods}

\section{Sampling}

Muscle samples were taken from 143 live crabs collected from six localities along three coastlines of Korea from 2009 to 2010 (Table 1, Fig. 1). The collected samples were stored at

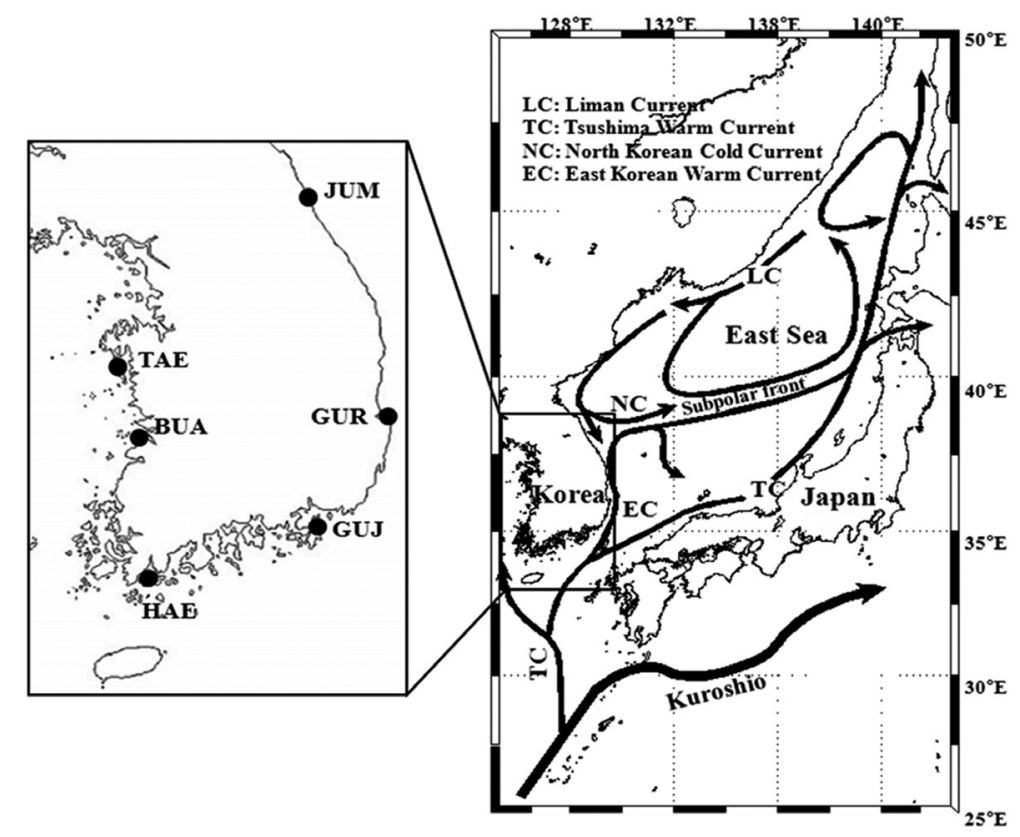

Fig. 1. Sampling locations of six Asian shore crab Hemigrapsus sanguineus populations and ocean current flow pattern in the Korean waters. BUA, Buan; GUJ, Geoje; GUR, Guryonpo; HAE, Haenam; JUM, Jumunjin; TAE, Taean.

Table 1. Sampling sites, and dates, geographical coordinates, number of individuals examined ( $n$ ), haplotype and nucleotide diversity ( $\pi$ ) of Asian shore crab Hemigrapsus sanguineus populations

\begin{tabular}{|c|c|c|c|c|c|c|c|c|}
\hline \multirow[t]{2}{*}{ Sampling site } & \multirow[t]{2}{*}{ Abbreviation } & \multirow{2}{*}{$\begin{array}{c}\text { Date of } \\
\text { collection }\end{array}$} & \multicolumn{2}{|c|}{ Geographical co-ordinates } & \multirow[t]{2}{*}{$n$} & \multirow{2}{*}{$\begin{array}{c}\text { No. of } \\
\text { haplotypes }\end{array}$} & \multirow{2}{*}{$\begin{array}{c}\text { Haplotype } \\
\text { diversity } \\
(h, \pm \mathrm{SD})\end{array}$} & \multirow{2}{*}{$\begin{array}{c}\text { Nucleotid } \\
\text { diversity } \\
(\pi)\end{array}$} \\
\hline & & & Latitude & Longitude & & & & \\
\hline Taean & TAE & June, 2009 & $36^{\circ} 28^{\prime} 10.40^{\prime \prime} \mathrm{N}$ & $126^{\circ} 26^{\prime} 07.19^{\prime \prime} \mathrm{E}$ & 24 & 6 & $0.616 \pm 0.0911$ & 0.0017 \\
\hline Buan & BUA & June, 2009 & $35^{\circ} 44^{\prime} 21.83^{\prime \prime} \mathrm{N}$ & $126^{\circ} 35^{\prime} 49.50^{\prime \prime} \mathrm{E}$ & 24 & 9 & $0.696 \pm 0.0962$ & 0.0021 \\
\hline Haenam & HAE & June, 2009 & $34^{\circ} 20^{\prime} 21.05^{\prime \prime} \mathrm{N}$ & $126^{\circ} 29^{\prime} 28.47^{\prime \prime} \mathrm{E}$ & 24 & 11 & $0.779 \pm 0.0815$ & 0.0028 \\
\hline Geoje & GUJ & April, 2010 & $34^{\circ} 54^{\prime} 18.50^{\prime \prime} \mathrm{N}$ & $128^{\circ} 44^{\prime} 52.55^{\prime \prime} \mathrm{E}$ & 24 & 7 & $0.634 \pm 0.0973$ & 0.0019 \\
\hline Guryonpo & GUR & April, 2010 & $36^{\circ} 03^{\prime} 33.00^{\prime \prime} \mathrm{N}$ & $129^{\circ} 31^{\prime} 17.12^{\prime \prime} \mathrm{E}$ & 24 & 13 & $0.880 \pm 0.0556$ & 0.0034 \\
\hline Jumunjin & JUM & April, 2009 & $37^{\circ} 53^{\prime} 38.53^{\prime \prime} \mathrm{N}$ & $128^{\circ} 50^{\prime} 06.77^{\prime \prime} \mathrm{E}$ & 23 & 11 & $0.778 \pm 0.0901$ & 0.0027 \\
\hline
\end{tabular}


$-20^{\circ} \mathrm{C}$ or kept in $100 \%$ ethanol at room temperature until used.

\section{PCR amplification and sequence analysis}

Genomic DNA was extracted from about $20 \mathrm{mg}$ of each specimen by a PUREGENE DNA isolation kit (Gentra Systems, Minneapolis, MN, USA) following the manufacturer's instructions. The purified DNA was dried at room temperature and dissolved in TE buffer (10 mM Tris-HCl, $1 \mathrm{mM}$ EDTA; $\mathrm{pH}$ 8.0). To amplify the Cytb gene, a pair of degenerate primers (Cyt9237 5'-GTWGCHCAYATTTGYCGAGA-3'; Cyt10050 5'-ACWGGKCGWGCWCCAATTCA-3') with expected amplicon sizes of $850 \mathrm{bp}$ was designed based on mtDNA sequences of the closely related crab species available in GenBank (AB093006, AY659990, AY562127, FJ797435, FJ827758-827761). The PCR amplification was performed with a thermocycler DNA Engine (MJ Research, Tokyo, Japan). in a $20-\mu \mathrm{L}$ reaction volume containing $1-2 \mu \mathrm{L}$ of genomic DNA, $2 \mu \mathrm{M}$ of each primer, $0.25 \mathrm{mM}$ of each dNTP, 1 unit of Takara LA Taq DNA polymerase (Takara Shuzo, Kyoto, Japan), and $2 \mu \mathrm{L}$ of $10 \times L A$ Taq reaction buffer (Takara Shuzo). The PCR conditions consisted of preheating at $94^{\circ} \mathrm{C}$ for $5 \mathrm{~min}$, followed by 35 cycles of $94^{\circ} \mathrm{C}$ for $30 \mathrm{~s}, 55^{\circ} \mathrm{C}$ for $30 \mathrm{~s}$, and $72^{\circ} \mathrm{C}$ for $30 \mathrm{~s}$, with final extensions at $72^{\circ} \mathrm{C}$ for $5 \mathrm{~min}$. The fragment size of the PCR product was verified using $2 \%$ agarose gel electrophoresis after ethidium bromide staining. The PCR product was purified with the AccuPrep PCR Purification Kit (Bioneer, Daejeon, Korea). After cycle sequencing with the ABI PRISM BigDye Terminator v3.1 Cycle Sequencing Ready Reaction Kit (Applied Biosystems, Foster City, CA, USA), the purified PCR product was sequenced directly on an ABI 3730xl DNA Analyzer (Applied Biosystems) with two newly designed internal primers, HsCytF (5'-GGGGTCAAATATCATTCTGG-3') and HsCytR (5'-GCCTTTGGAATTTTGAAGAG-3').

\section{Data analysis}

The sequence fragments obtained in this study were aligned with GENETIX-WIN ver. 4.0.1 (Software Development, Tokyo, Japan) to identify sequence variants. The integrated software package DnaSP version 5 (Librado and Rozas, 2009) was used to determine the genotypes or haplotypes. A parsimony network connecting the observed haplotypes to resolve the genealogy was plotted with TCS version 1.21 (Clement et al., 2000). Genetic variation within the populations, expressed as haplotype diversity $(h)$ and nucleotide diversity $(\pi)$, was estimated according to Nei (1987) based on Kimura's twoparameter distance method using K and DA in the REAP program (McElroy et al., 1992). Pairwise population $F_{\mathrm{ST}}$ values were calculated to estimate the genetic differentiation among the populations according to Slatkin and Hudson (1991) using ARLEQUIN version 3.1 (Excoffier et al., 2005). The significance of each $F_{\mathrm{ST}}$ value was tested using 10,000 random permutations. Gene flow among populations was estimated with $N_{\mathrm{e}} \mathrm{m}$, the number of migrations per generation between population pairs (Slatkin, 1993) using the following equation:

$$
N_{\mathrm{e}} \mathrm{m}=\left(1 / F_{\mathrm{ST}}-1\right) / 4,
$$

where $N$ is the effective population size, $\mathrm{m}$ is the effective proportion of immigrants, and $F_{\mathrm{ST}}$ is the fixation index. To examine the relationships among populations visually, we used a two-dimensional scaling (TDS) analysis based on the matrix of pairwise $F_{\mathrm{ST}}$ values from the $C y t \mathrm{~b}$ sequence data calculated by SPSS version 14.0K (SPSS, Inc., Chicago, IL, USA).

Neutral expectation and historic demographic expansions were investigated by examining Fu's $F_{S}$ and Tajima's $D$ and mismatch distributions with the sudden expansion model (Rogers and Harpending, 1992). A goodness-of-fit test was used to test the validity of the sudden-expansion model using a parametric bootstrap approach based on the sum of squared deviations (SSD) to compare the observed and estimated mismatch distributions (Schneider and Excoffier, 1999). Both the neutrality test and mismatch distribution analysis were performed in ARLEQUIN version 2000 (Schneider et al., 2000). Since the mutation rate of the H. sanguineus Cytb gene over the estimated time since expansion was unknown, a molecular clock was calculated using the sequence-divergence rates of mitochondrial protein coding regions for other marine crustaceans; rates ranged from 2.2 to $3.1 \%$ per million years (Knowlton and Weigt, 1998; Schubart et al., 1998).

\section{Results}

\section{Cytb variation in H. sanguineus}

The degenerate primers newly designed in this study (Cyt9237 and Cyt10050) successfully amplified the mtDNA Cytb region of the 143 H. sanguineus individuals. Direct sequencing of the PCR products with two internal primers (Hs$\mathrm{CytF}$ and HsCytR) yielded a fragment with an amplicon size of $470 \mathrm{bp}$, which revealed 38 variable nucleotide sites defining 37 haplotypes among the populations (Table 2). The variable nucleotide sites observed consisted of 33 transitions and four transversions. All substitutions were biallelic except one, which was triallelic, suggesting the occurrence of a single base substitution among sequences. The nucleotide sequences of the 37 haplotypes have been deposited in the DDBJ/GenBank database under accession numbers AB570203-AB570239.

The parsimony network of the Cytb haplotypes in H. sanguineus did not provide evidence of geographical association (Fig. 2). In the network, two focal haplotypes, HeS1 and HeS12, were abundant, whereas the others, including singletons, were rare and radiated from these focal haplotypes. The distribution of the 37 haplotypes among the six H. sanguineus populations is presented in Table 3. Among them, 28 were found at single localities, and nine (HeS1, HeS4, HeS9, 


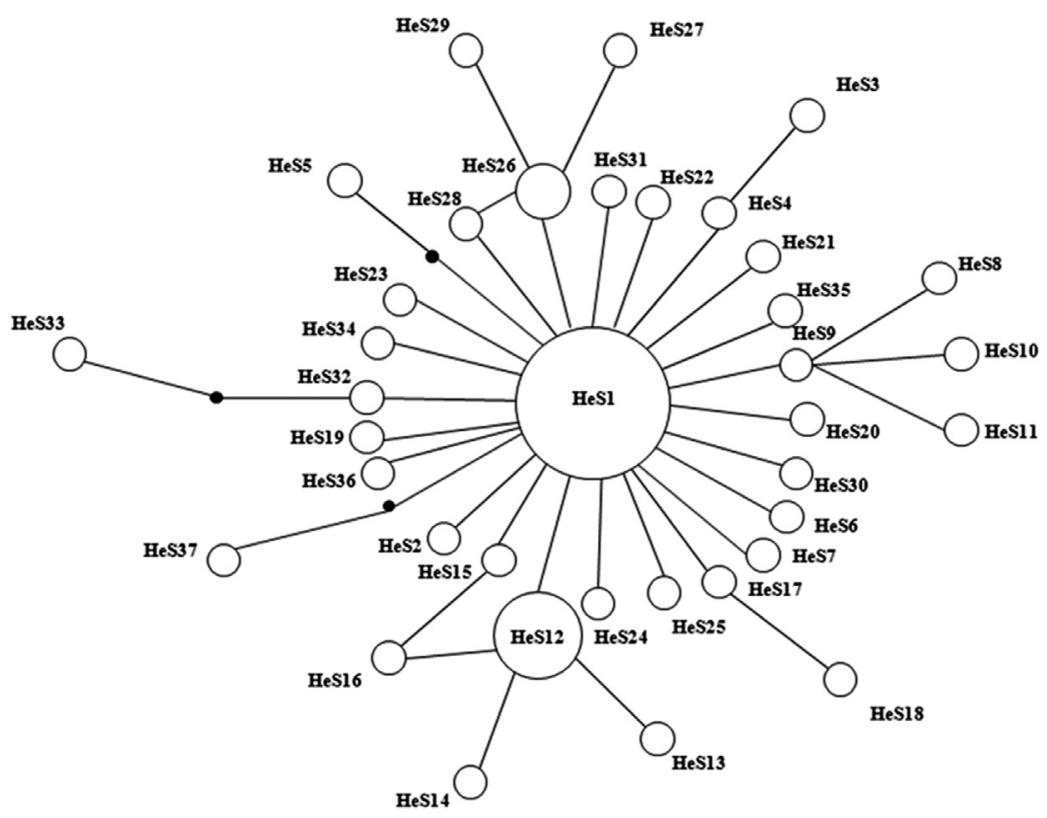

Fig. 2. A single minimum spanning tree for the 38 mitochondrial cytochrome $b$ region haplotypes of Asian shore crab Hemigrapsus sanguineus (Table 2). Circle sizes reflect haplotype abundance..

Table 2. Variable nucleotide sites in 470 bp sequences of mitochondrial cytochrome $b$ gene partial sequences in Asian shore crab Hemigrapsus sanguineus

\begin{tabular}{|c|c|c|c|c|c|c|c|c|c|c|c|c|c|c|c|c|c|c|c|c|c|c|c|c|c|c|c|c|c|c|c|c|c|c|c|c|}
\hline \multirow{2}{*}{ Haplotype } & \multicolumn{36}{|c|}{ Variable nucleotide sites } \\
\hline & 2 & & & & & & & & & $\begin{array}{l}1 \\
3 \\
7\end{array}$ & & & $\begin{array}{l}1 \\
7 \\
9\end{array}$ & $\begin{array}{ll}1 & 1 \\
8 & 5 \\
8 & 7\end{array}$ & & $\begin{array}{l}2 \\
1 \\
5\end{array}$ & $\begin{array}{l}2 \\
2 \\
7\end{array}$ & & $\begin{array}{l}2 \\
6 \\
3\end{array}$ & & & $\begin{array}{l}2 \\
8 \\
5\end{array}$ & & & $\begin{array}{l}3 \\
2 \\
0\end{array}$ & & & & & & $\begin{array}{l}3 \\
6 \\
8\end{array}$ & & & & $\begin{array}{ll}4 & 4 \\
3 & 5 \\
7 & 5 \\
\end{array}$ & $\begin{array}{l}4 \\
7 \\
0\end{array}$ \\
\hline & A & & $\mathrm{C}$ & & G & A & $\mathrm{T}$ & T & $\mathrm{G}$ & & & & & $\mathrm{G}$ & & $\mathrm{A}$ & $\mathrm{A}$ & $\mathrm{C}$ & & & $\mathrm{G}$ & $\mathrm{A}$ & & A & & & & & & & & & & & & $\mathrm{A}$ \\
\hline & & & & & & . & . & & & & & & & & & & & & $\mathrm{C}$ & . & . & & . & · & . & & & & & & & & & & . & \\
\hline & & . & . & & . & . & . & . & . & . & & & & & & . & . & & & . & . & . & . & G & & & $\mathrm{C}$ & . & & & . & . & & & . & \\
\hline & • & . & . & . & . & . & - & . & . & & & & & & & . & & & & & . & . & . & G & & & . & . & - & . & . & - & . & ( & . & \\
\hline & & . & - & & . & . & . & $\mathrm{C}$ & . & & & & & & & . & & $\mathrm{T}$ & . & & . & . & . & & & & . & . & & . & . & . & . & & . & \\
\hline & & . & . & & . & . & . & & . & & • & & & & & . & . & & . & . & . & . & . & . & & & & . & & . & & & G & 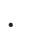 & . & \\
\hline & & . & - & & & - & - & - & . & . & & & & & $\mathrm{c}$ & . & . & & . & . & . & . & . & & . & & & & & & & & & & . & \\
\hline & & . & . & . & . & . & . & - & . & & & & & & & . & . & & . & . & A & & . & . & . & & & . & . & & & & & & & \\
\hline & & . & . & . & . & . & . & . & . & . & & & & & & . & . & & & . & A & . & . & . & . & & . & . & . & & & . & . & & . & \\
\hline & & . & . & . & . & . & • & & • & & & & & & & . & . & & & . & A & . & . & . & . & & . & . & . & . & & . & & & . & \\
\hline & & . & . & . & . & . & . & . & . & & & & & & & . & & & . & . & A & . & . & . & . & & & A & . & . & • & . & . & & . & \\
\hline & & . & . & & . & . & . & . & . & & & & & & & . & 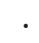 & & . & . & . & . & . & . & . & & & . & & A & . & . & . & & . & \\
\hline & & . & . & . & . & . & . & . & . & & & & & & & . & G & 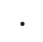 & . & . & . & . & . & . & . & & . & . & & A & & . & . & & . & \\
\hline & & . & $\cdot$ & & . & . & . & . & . & . & & & & & & . & & & . & . & . & . & . & . & . & & & . & & A & & & . & & . & \\
\hline & & . & & C & & . & . & & . & & & & & & & . & . & & . & . & . & . & . & . & . & & & . & & & & . & & & & \\
\hline & & . & & C & & . & . & . & . & & & & & & & . & . & & & . & . & . & . & . & 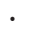 & & . & . & & A & & & & & . & \\
\hline & & . & . & & . & . & . & . & $\cdot$ & & & & & & & . & . & & & . & . & . & . & . & . & & . & . & & & & & & & . & \\
\hline & & . & . & & & & & & & & & & & & & 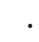 & . & & & . & . & & . & . & . & & & & & & & & & & . & \\
\hline & & . & & & & . & & & & & & & & & & & & & & & . & & & & & & & & $\mathrm{C}$ & & & . & & & . & \\
\hline & & . & & & & & & & & & & & & & & $\mathrm{G}$ & & & & & . & & & & & & & . & & & & & & & . & \\
\hline & & . & . & & . & . & . & . & 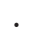 & . & . & & 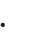 & & & & . & & . & . & . & . & . & . & . & & . & . & & 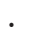 & • & . & & & C & \\
\hline & & . & . & & $\mathrm{T}$ & & . & . & . & & & & & & & . & 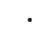 & & & . & . & . & . & . & . & & & & & & & & & & . & \\
\hline & G & & . & & & . & . & & . & & & & & & & . & & & & . & . & . & . & . & . & & & . & & & & & & & . & \\
\hline & & & $\mathrm{T}$ & & & & & & & & & & & & & & & & & & . & . & . & & & & & & & & & & & & & \\
\hline & & . & & & & . & . & & . & & & & & & & & & & & & . & & & & & & & & & & & & & & & \\
\hline & & . & & & & & & & A & & & & & & & & & & & & & & & & & & & & & & & & & & & \\
\hline & & G & & & . & & & . & A & & & & & & & & & & & & . & & & & & & & & & & & . & & & . & \\
\hline & & . & · & & . & . & . & . & C & • & & & & & & . & & & & . & . & . & . & . & . & & . & . & & & & . & & & . & \\
\hline & & . & . & & & G & & & & & & & & & & & & & & . & . & . & . & . & . & & & & & & & & & & . & \\
\hline & & . & . & & & & & & & & & & & & & & & & & . & . & & & & & & & & & & & & & & & \\
\hline & & & & & & & & & & & & & & & & & & & & & & & & & & & & & & & & & & & & \\
\hline & & . & & & & & & & & & & & & & & & & & & . & . & & & & & & & & & & & & & & & \\
\hline & & . & . & & & . & & & & & & & & & & & & & & & . & $\mathrm{G}$ & & & & & & & & & & & & & . & \\
\hline & & . & & & & . & & & & & & & & & & & & & & & & & & & & & & & & & & & & & & \\
\hline & & & & & & & & & & & & & & & & & & & & & & & & & & & & & & & & & & & & \\
\hline & & & & & & & & & & & & & & & & & & & & & & & & & & & & & & & & & & & . & \\
\hline HeS37 & & & & & & & & & & & & & & & & & & & & & & & & & & & & & & & & & & & . . & \\
\hline
\end{tabular}


Table 3. Distribution of mitochondrial cytochrome $b$ haplotypes among 6 populations of Asian shore crab Hemigrapsus sanguineus. Sampling site abbreviations (first row) are listed in Table 1

\begin{tabular}{|c|c|c|c|c|c|c|c|}
\hline & TAE & BUA & HAE & GUJ & GUR & JUM & Total \\
\hline $\mathrm{HeS} 1$ & 14 & 43 & 11 & 14 & 8 & 11 & 101 \\
\hline $\mathrm{HeS} 2$ & & & & & & 1 & 1 \\
\hline $\mathrm{HeS} 3$ & 1 & & & & & & 1 \\
\hline $\mathrm{HeS} 4$ & & 1 & & & 1 & & 2 \\
\hline HeS5 & & & & & 1 & & 1 \\
\hline HeS6 & & & & 1 & & & 1 \\
\hline HeS7 & & & 1 & & & & 1 \\
\hline HeS8 & & & & & & 2 & 2 \\
\hline HeS9 & & & 1 & & 1 & & 2 \\
\hline $\mathrm{HeS} 10$ & & 1 & & & & & 1 \\
\hline HeS11 & & & & & & 1 & 1 \\
\hline $\mathrm{HeS} 12$ & 6 & 4 & 4 & 5 & 3 & & 22 \\
\hline $\mathrm{HeS} 13$ & & 1 & & & & & 1 \\
\hline $\mathrm{HeS} 14$ & & & & & 1 & & 1 \\
\hline HeS15 & & & 1 & & & & 1 \\
\hline HeS16 & & & 1 & & & & 1 \\
\hline $\mathrm{HeS} 17$ & & & & & & 1 & 1 \\
\hline $\mathrm{HeS} 18$ & & & 1 & & & & 1 \\
\hline HeS19 & & & & & 1 & & 1 \\
\hline $\mathrm{HeS} 20$ & & 1 & & & & & 1 \\
\hline HeS21 & & & 1 & & 1 & & 2 \\
\hline $\mathrm{HeS} 22$ & & & & & & 2 & 2 \\
\hline $\mathrm{HeS} 23$ & & & & & & 1 & 1 \\
\hline $\mathrm{HeS} 24$ & & & & & & 1 & 1 \\
\hline $\mathrm{HeS} 25$ & & & & & & 1 & 1 \\
\hline HeS26 & 1 & 1 & 1 & 1 & 2 & & 6 \\
\hline $\mathrm{HeS} 27$ & & & & 1 & & & 1 \\
\hline $\mathrm{HeS} 28$ & & & & 1 & & & 1 \\
\hline HeS29 & & & & & 1 & & 1 \\
\hline $\mathrm{HeS} 30$ & & 1 & & 1 & 1 & & 3 \\
\hline HeS31 & & 1 & & & & & 1 \\
\hline $\mathrm{HeS} 32$ & & & 1 & & & 1 & 2 \\
\hline HeS33 & & & 1 & & & & 1 \\
\hline $\mathrm{HeS} 34$ & & & & & & 1 & 1 \\
\hline HeS35 & 1 & & & & 2 & & 3 \\
\hline HeS36 & 1 & & & & & & 1 \\
\hline HeS37 & & & & & 1 & & 1 \\
\hline
\end{tabular}

HeS12, HeS21, HeS26, HeS30, HeS32, and HeS35) were observed in two or more localities. A number of individuals from the populations examined had the HeS12 and HeS26 haplotypes, although these were not found in JUM. HeS1 occurred in all populations.

The haplotype and nucleotide diversities of $H$. sanguineus demonstrated varying levels of genetic variation among populations. Variation was higher in the Guryonpo (GUR), Haenam (HAE), and Jumunjin (JUM) populations (Table 1). Reduced haplotype diversity was observed in the Taean (TAE), Buan (BUA), and Geoje (GUJ) populations.

\section{Population genetic analysis}

The pairwise population $F_{\mathrm{ST}}$ estimates and migration rate based on the Cytb sequences are presented in Table 4. Most pairwise values were not significantly different among populations. Although the pairwise $F_{\mathrm{ST}}$ estimates showed no clear genetic differentiation (low values among populations), the

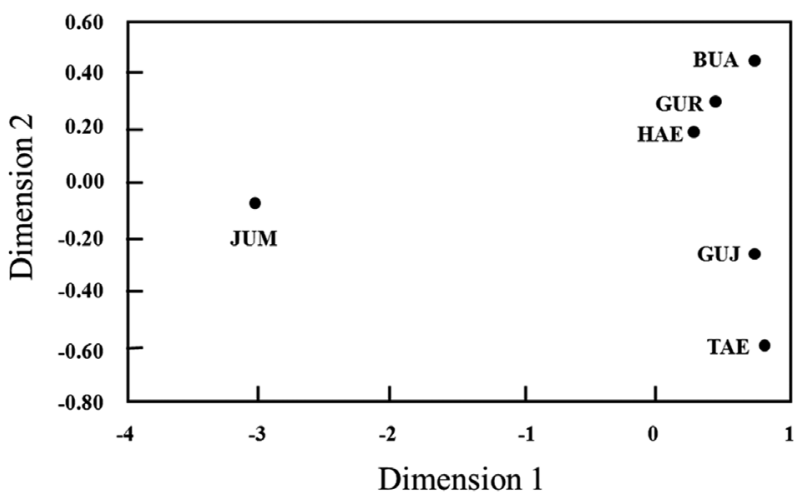

Fig. 3. Two-dimensional scaling analysis based on the matrix of pairwise $F_{\mathrm{ST}}$ values from the mitochondrial cytochrome $b$ sequence data for Asian shore crab Hemigrapsus sanguineus. BUA, Buan; GUJ, Geoje; GUR, Guryonpo; HAE, Haenam; JUM, Jumunjin; TAE, Taean.

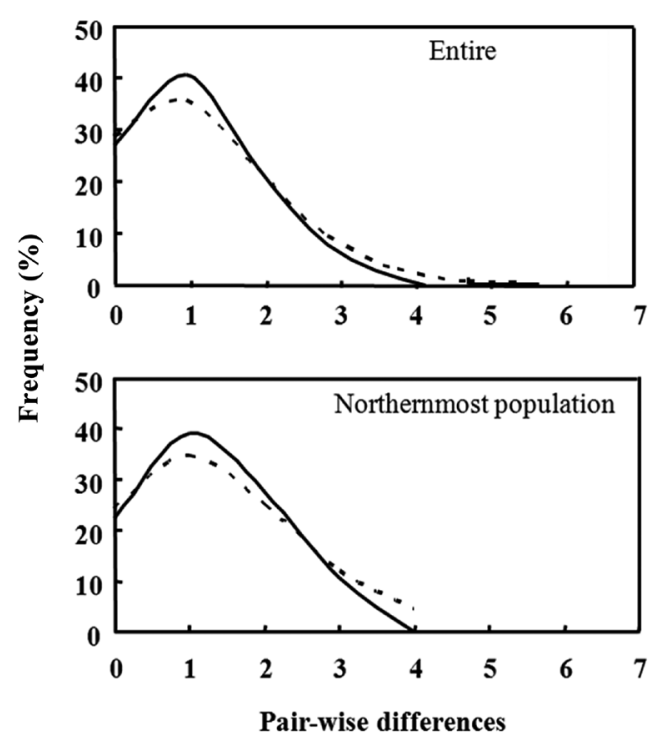

Fig. 4. Mismatch distribution constructed using pairwise differences among mitochondrial DNA (mtDNA) haplotypes of Asian shore crab Hemigrapsus sanguineus from the pooled populations and from a single northeastern population (Jumunjin [JUM]). Solid lines, observed frequency; dashed lines, frequency distribution expected from a sudden expansion model.

pairwise population $F_{\mathrm{ST}}$ estimates were large when JUM was compared with the other populations. These findings were evident in the TDS analysis and $N_{\mathrm{e}} \mathrm{m}$ values (Fig. 3). Overall, the TAE, BUA, HAE, GUJ, and GUR populations were genetically close to one another, but distinct from JUM.

Mismatch distributions for all populations pooled and the northernmost population (JUM) are shown in Fig. 4. The pooled populations and JUM had no additional distribution peaks; the highest frequency occurred at one difference. The $D$, Fu's $F_{S}$, and SSD (Table 5) values indicated expansion in these populations. Tajima's D and Fu's $F_{S}$ were significantly negative, with markedly reduced SSD in the pooled popula- 
Table 4. Pairwise $F_{\mathrm{ST}}$ (below the diagonal) and $N_{\mathrm{e}} \mathrm{m}$ (above the diagonal) estimates among the six populations of Asian shore crab Hemigrapsus sanguineus.

\begin{tabular}{lcccccc}
\hline & TAE & BUA & HAE & GUJ & GUR & JUM \\
\hline TAE & & 11.1 & 28.0 & 14.1 & 23 & 3.5 \\
BUA & -0.023 & & 21.1 & 12.8 & 18 & 6.3 \\
HAE & -0.009 & -0.012 & & 31.5 & 50.3 & 7.8 \\
GUJ & -0.018 & -0.020 & -0.008 & & 15.9 & 4.3 \\
GUR & -0.011 & -0.014 & -0.005 & -0.016 & & 8.0 \\
JUM & $0.067^{*}$ & $0.038^{*}$ & $0.031^{*}$ & $0.055^{*}$ & $0.030^{*}$ & \\
\hline
\end{tabular}

TAE, Taean; BUA, Buan; HAE, Haenam; GUJ, Geoje; GUR, Guryonpo; JUM, Jumunjin.

*Significant differentiation $(P<0.05)$ on the exact test (Raymond and Rousset, 1995).

tion group and JUM population, a parameter combination that strongly supported sudden expansion. Sudden expansion of the pooled population group was estimated to have occurred 0.042-0.060 million years ago (Ma) and that in the JUM population, 0.049-0.069 Ma (Table 5).

\section{Discussion}

The genetic variation analysis of the mitochondrial $C y t b$ gene revealed the followings: (i) haplotype and nucleotide diversity occurred at various levels of genetic variation and (ii) there was a low level of genetic differentiation in coastal areas of Korea, but there was some genetic differentiation of the northernmost population (JUM) in the East Sea from the other populations. The observed haplotypes from the Cytb region in H. sanguineus were arrayed in star-like genealogies, each with several closely related, low-frequency haplotypes around a central high-frequency haplotype, suggesting a shallow haplotype genealogy. The star-like pattern and shallow genealogy indicate recent appearance and rapid population growth (Slatkin and Hudson, 1991; Rogers and Harpending, 1992). Our estimates showed that $H$. sanguineus began expanding 42,862-60,396 years ago (Table 5). High haplotype diversity (0.616-0.880) but low nucleotide diversity (0.0017-0.0034) within the populations indicates that the populations might have experienced historically rapid population growth from an ancestral population with a small effective population size in the Late Pleistocene (Avise, 2000).
A reduced genetic diversity in the TAE and BUA populations from the west coast in the Yellow Sea compared with the other regional populations, except the GUJ population, was observed from the haplotype and nucleotide diversities. The western Korean populations showed no genetic differentiation from the southern populations as inferred from the pairwise $F_{\text {ST }}$ values. Therefore, crabs might have been introduced continuously with high rates of gene flow to the TAE and BUA populations from other sources following a reduction in effective population size.

The estimated pairwise $F_{\mathrm{ST}}$ values, $N_{\mathrm{e}} \mathrm{m}$ rate, and TDS analysis indicate that substantial gene flow has occurred among the populations, suggesting that larval behavior and sea currents are responsible for the high rates of gene flow. The passive dispersal of planktonic larvae and sedentary lifestyle of adult marine invertebrates limit the formation of population substructure (Lessios et al., 2003; Waters and Roy, 2004). Many other marine crab species reportedly have high levels of gene flow between populations or regions (Beckwitt, 1985; Merkouris et al., 1998; Azuma et al., 2008). Hwang et al. (1993) reported that the planktonic larval stage of $H$. sanguineus persists for 25 days until metamorphosis on the sea floor to form the first crab stage. In general, crustacean species with similar persistent pelagic larval stages have a high dispersal potential that produces genetic homogeneity among local populations (Palumbi, 1994). The Tsushima Warm Current (TC) branches off the Kuroshio Current, with part of the TC running into the Yellow Sea and the main part entering the East Sea along the Korean Peninsula (Fig. 1). Therefore, the TC might transport $H$. sanguineus larvae to the western coast of Korea.

Despite the lack of geographically associated haplotypes and genetic structure within and among populations, our analyses indicated a degree of genetic differentiation between the northernmost population (JUM) in the East Sea and the other populations. The sub-polar front in the East Sea is similar to the western boundary current in that a polar front forms at the boundary between the low-temperature, low-salinity waters of the northern region and the high-temperature, high-salinity waters of the southern region (Rhein et al., 1995; Pickart et al., 1997). The sub-polar front, which extends along the coast of Japan before turning abruptly at the Noto Peninsula frontal region toward the center of the East Sea, has a close relationship to the TC and cold-water currents, including the Liman Current (LC) (Senjyu, 1999; Ichikawa and Beardsley, 2002) (Fig. 1). Restricted or se-

Table 5. Asian shore crab Hemigrapsus sanguineus: parameters of the sudden expansion model and estimated time since expansion

\begin{tabular}{ccccccccc}
\hline Populations & $\begin{array}{c}\text { Sample } \\
\text { size }\end{array}$ & $\begin{array}{c}\boldsymbol{D} \\
(\boldsymbol{P} \text {-value })\end{array}$ & $\begin{array}{c}\boldsymbol{F}_{\boldsymbol{S}} \\
(\boldsymbol{P} \text {-value })\end{array}$ & $\begin{array}{c}\text { SSD } \\
(\boldsymbol{P} \text {-value })\end{array}$ & $\begin{array}{c}\boldsymbol{\tau} \\
(\mathbf{9 5 \%} \mathbf{C I})\end{array}$ & $\begin{array}{c}\boldsymbol{\theta}_{\mathbf{0}} \\
(\mathbf{9 5 \%} \text { CI) }\end{array}$ & $\begin{array}{c}\boldsymbol{\theta}_{\mathbf{1}} \\
(\mathbf{9 5 \%} \mathbf{C I})\end{array}$ & $\begin{array}{c}\text { Time since } \\
\text { expansion (y) }\end{array}$ \\
\hline \multirow{2}{*}{ Entire } & \multirow{2}{*}{143} & -2.491 & -29.249 & 0.003 & 1.249 & 0.000 & $2,071.875$ & $42,862-60,397$ \\
& & $(0.001)$ & $(0.000)$ & $(0.059)$ & $(0.538-1.519)$ & $(0.000-0.742)$ & $(7.677-5,351.875)$ & \\
\multirow{2}{*}{ JUM } & 23 & -1.970 & -8.261 & 0.004 & 1.440 & 0.000 & $1,905.000$ & $49,417-69,633$ \\
& & $(0.013)$ & $(0.000)$ & $(0.482)$ & $(0.184-2.205)$ & $(0.000-1.493)$ & $(11.560-6,730.000)$ & \\
\hline
\end{tabular}

$D$, Tajima's $D ; F_{s}$ Fu's $F_{s}$; SSD, sum of squared deviations in the goodness of-fit-test; $\tau$, time since expansion measured in mutational time units; $C l$, confidence interval; $\theta_{0}$ and $\theta_{1}$, population sizes scaled by mutation rate before and after expansion, respectively. 
lective gene flow from main distributions can result from such physical barriers, which restrict larval transport (Hedgecock, 1986; Scheltema, 1986; Bowen and Avise, 1990; Palumbi, 1994; Burton, 1998). The JUM population is located at the sub-polar front, where the cold and warm currents of the East Sea meet. Therefore, the balanced effects of the cold (LC) and warm (TC) water currents in the East Sea might explain the genetic differentiation between the JUM population and other wild populations.

The mismatch distribution in our data was unimodal, and the neutrality test gave a significantly negative value, suggesting recent population expansion of $H$. sanguineus in Korea. Estimates of other mismatch distribution parameters corroborate this evidence. Therefore, H. sanguineus population expansion in Korean coastal waters resulted from rapid population growth and recent, sudden expansion in the Late Pleistocene. This was corroborated by the star-like genealogy of the haplotypes, high haplotype diversities, close genetic similarities among haplotypes, mismatch distribution pattern supporting a sudden expansion model, and estimated expansion time. However, this perspective remains ambiguous, and further extended sampling from Hong Kong through Japan to Russia is necessary to clarify the historical influences.

Based on our results, the $H$. sanguineus populations might be one large panmictic population in Korean coastal waters, with the exception of the northeastern population. This genetic information about the current condition of $H$. sanguineus will be useful in developing a conservation strategy and subsequent ecological monitoring. $H$. sanguineus has colonized the eastern coast of the USA, Atlantic France, and the Netherlands in recent years. Comparative studies of genetic variation and structure in donor and invader populations using the molecular procedures employed in this study are essential for developing a greater understanding of the spatiotemporal invasion-pattern mechanism. Finally, we demonstrated that genetic variation analysis using mtDNA Cytb sequences is a useful model for research on population-level studies in closely related species.

\section{Acknowledgments}

This research was a part of the project titled "East Asian Seas Time Series - I (EAST-I)" and "Long-term change of structure and function in marine ecosystems of Korea" funded by the Ministry of Land, Transport and Maritime Affairs, Korea.

\section{References}

Anderson S, Bankier AT, Barrell BG, de Bruijn MHL, Coulson AR, Drouin J, Eperon IC, Nierlich DP, Roe BA, Sanger F, Schreier PH, Smith AJH, Staden R and Young IG. 1981. Sequence and organization of the human mitochondrial genome. Nature 290, 457-465.

Avise JC. 2000. Phylogeography: the History and Formation of Species.
Harvard University Press, Cambridge, MA, US.

Azuma N, Kunihiro Y, Sasaki J, Mihara E, Mihara Y, Yasunaga T, Jin DH and Abe S. 2008. Genetic variation and population structure of hair crab (Erimacrus isenbeckii) in Japan inferred from mitochondrial DNA sequence analysis. Mar Biotechnol 10, 39-48.

Beckwitt R. 1985. Population genetics of the sand crab, Emerita analoga Stimpson, in southern California. J Exp Mar Biol Ecol 91, 45-52.

Bilton DT, Paula J and Bishop JDD. 2002. Dispersal, genetic differentiation and speciation in estuarine organisms. Estuar Coast Shelf Sci 55, 937-952.

Bowen BW and Avise JC. 1990. Genetic structure of Atlantic and Gulf of Mexico populations of sea bass, menhaden, and sturgeon influence of zoogeographic factors and life-history patterns. Mar Biol 107, 371-381.

Brown WM, George M Jr and Wilson AC. 1979. Rapid evolution of animal mitochondrial DNA. Proc Natl Acad Sci U S A 76, 1967-1971.

Burton RS. 1998. Intraspecific phylogeography across the Point Conception biogeographic boundary. Evolution 52, 734-745.

Cassone BJ and Boulding EG. 2006. Genetic structure and phylogeography of the lined shore crab, Pachygrapsus crassipes, along the northeastern and western Pacific coasts. Mar Biol 149, 213-226.

Clement M, Posada D and Crandall KA. 2000. TCS: a computer program to estimate gene genealogies. Mol Ecol 9, 1657-1659.

Creasey S, Rogers AD, Tyler P, Young C and Gage J. 1997. The population biology and genetics of the deep-sea spider crab, Encephaloides armstrongi Wood-Mason 1891 (Decapoda: Majidae). Philos Trans R Soc Lond B Biol Sci 352, 365-379.

Dai AY and Yang SL. 1991. Crabs of the China Seas. China Ocean Press, Beijing, CN.

Doyle MJ, Morse WW and Kendall AW Jr. 1993. A comparison of larval fish assemblages in the temperate zone of the northeast Pacific and northwest Atlantic Oceans. Bull Mar Sci 53, 588-644.

Dunham RA. 2004. Aquaculture and Fisheries Biotechnology. CABI Publishing Press, Wallingford, GB.

Excoffier L, Laval G and Schneider S. 2005. Arlequin (version 3.0): an integrated software package for population genetics data analysis. Evol Bioinform Online 1, 47-50.

Fukui Y. 1988. Comparative studies on the life history of the grapsid crabs (Crustacea, Brachyura) inhabiting intertidal cobble and boulder shores. Publ Seto Mar Biol Lab 33, 121-162.

Hedgecock D. 1986. Is gene flow from pelagic larval dispersal important in the adaptation and evolution of marine invertebrates? Bull Mar Sci 39, 550-564.

Hsieh HY, Lo WT, Liu DC and Su CW. 2010. Influence of hydrographic features on larval fish distribution during the south-westerly monsoon in the waters of Taiwan, western North Pacific Ocean. J Fish Biol 76, 2521-2539.

Hwang SG, Lee C and Kim CH. 1993. Complete larval development of Hemigrapsus sanguineus (Decapoda, Brachyura, Grapsidae) reared in the laboratory. Korean J Syst Zool 9, 69-86.

Ichikawa H and Beardsley RC. 2002. The current system in the Yellow and East China Seas. J Oceanogr 58, 77-92.

Kikuchi T, Tanaka M, Nojima S and Takahashi T. 1981. Ecological studies on the pebble crab, Gaetice depressus (de Haan). I. Eco- 
logical distribution of the crab and environmental conditions. Publ Amakusa Mar Biol Lab 6, 23-34.

Knowlton N and Weigt LA. 1998. New dates and new rates for divergence across the Isthmus of Panama. Proc R Soc Lond B Biol Sci 265, 2257-2263.

Lessios HA, Kane J and Robertson DR. 2003. Phylogeography of the pantropical sea urchin Tripneustes: Contrasting patterns of population structure between oceans. Evolution 57, 2026-2036.

Librado P and Rozas J, 2009. DnaSP v5: a software for comprehensive analysis of DNA polymorphism data. Bioinformatics 25, 14511452.

Lohrer AM, Fukui Y, Wada K and Whitlatch RB. 2000. Structural complexity and vertical zonation of intertidal crabs, with focus on habitat requirements of the invasive Asian shore crab, Hemigrapsus sanguineus (de Haan). J Exp Mar Biol Ecol 244, 203-217.

McDermott JJ. 1998a. The western Pacific brachyuran Hemigrapsus sanguineus (Grapsidae) in its new habitat along the Atlantic coast of the Untied States: reproduction. J Crustac Biol 18, 308-316.

McDermott JJ. 1998b. The western Pacific brachyuran (Hemigrapsus sanguineus: Grapsidae), in its new habitat along the Atlantic coast of the Untied States: geographic distribution and ecology. ICES J Mar Sci 55, 289-298.

McElroy D, Moran P, Bermingham E and Kornfield I. 1992. REAP: An integrated environment for the manipulation and phylogenetic analysis of restriction data. J Hered 83, 157-158.

McMillen-Jackson AL, Bert TM and Steele P. 1994. Population genetics of the blue crab Callinectes sapidus: modest population structuring in a background of high gene flow. Mar Biol 118, 53-65.

Merkouris SE, Seeb LW and Murphy MC. 1998. Low levels of genetic diversity in highly exploited populations of Alaskan tanner crabs, Chionoecetes bairdi, and Alaskan and Atlantic snow crabs, $C$. opilio. Fish Bull 96, 525-537.

Nei M. 1987. Molecular Evolutionary Genetics. Columbia University Press, New York, US.

Palumbi SR. 1994. Genetic divergence, reproductive isolation, and marine speciation. Annu Rev Ecol Syst 25, 547-572.

Pfeiler E, Hurtado LA, Knowles LL, Torre-Cosío J, Bourillón-Moreno L, Márquez-Farías JF and Montemayor-López G. 2005. Population genetics of the swimming crab Callinectes bellicosus (Brachyura: Portunidae) from the eastern Pacific Ocean. Mar Biol 146, 559. 569.

Pickart RS, Spall MA and Lazier JRN. 1997. Mid-depth ventilation in the western boundary current system of the sub-polar gyre. Deep Sea Res Part I Oceanogr Res Pap 44, 1025-1054.
Raymond M and Rousset F. 1995. An exact test for population differentiation. Evolution 49, 1280-1283.

Rhein M, Stramma L and Send U. 1995. The Atlantic deep western boundary current: water masses and transports near the equator. $\mathrm{J}$ Geophys Res 100, 2441-2457.

Rogers AR and Harpending H. 1992. Population growth makes waves in the distribution of pairwise genetic differences. Mol Biol Evol 9, 552-569.

Sakai T. 1976. Crabs of Japan and the Adjacent Seas. Kodansha Ltd., Tokyo, JP.

Scheltema RS. 1986. On dispersal and planktonic larvae of benthic invertebrates: an eclectic overview and summary of problems. Bull Mar Sci 39: 290-322

Schneider S and Excoffier L. 1999. Estimation of past demographic parameters from the distribution of pairwise differences when the mutation rates vary among sites: application to human mitochondrial DNA. Genetics 152, 1079-1089.

Schneider S, Roessli D and Excoffier L. 2000. Arlequin: a Software for Population Genetics Data Analysis. User Manual Ver. 2.000. Genetics and Biometry Laboratory, Department of Anthropology, University of Geneva, Geneva, $\mathrm{CH}$.

Schubart CD, Diesel R and Hedges SB. 1998. Rapid evolution to terrestrial life in Jamaican crabs. Nature 393, 363-365.

Senjyu T. 1999. The Japan Sea intermediate water: its characteristics and circulation. J Oceanogr 55, 111-122.

Slatkin M. 1993. Isolation by distance in equilibrium and non-equilibrium populations. Evolution 47, 264-279.

Slatkin M and Hudson RR. 1991. Pairwise comparisons of mitochondrial DNA sequences in stable and exponentially growing populations. Genetics 129, 555-562.

Takada Y and Kikuchi T. 1991. Seasonal and vertical variation of the boulder shore fauna in Amakusa. Publ Amakusa Mar Biol Lab 11, 1-17.

Wang C, Li C and Li S. 2008. Mitochondrial DNA-inferred population structure and demographic history of the mitten crab (Eriocheir sensu stricto) found along the coast of mainland China. Mol Ecol 17, 3515-3527.

Wares JP, Gaines SD and Cunningham CW. 2001. A comparative study of asymmetric migration events across a marine biogeographic boundary. Evolution 55, 295-306.

Waters JM and Roy MS. 2004. Phylogeography of a high-dispersal New Zealand sea-star: does upwelling block gene-flow? Mol Ecol 13, 2797-2806. 